\title{
Implementasi Program Kampung BANTAR (Bersih, Aman dan Pintar) di Kelurahan Eka Jaya Kecamatan Paal Merah Kota Jambi
}

\author{
Oktaviani, Henni Muchtar \\ Program Studi Pendidikan Pancasila dan Kewarganegaraan \\ Universitas Negeri Padang \\ E-mail: oktavianivia802@gmail.com
}

\begin{abstract}
ABSTRAK
Program Kampung bersih, aman dan pintar merupakan Program Pemerintah Kota Jambi yang bertujuan untuk menjadikan perkampungan terkecil lingkup RT (rukun tetangga) memiliki wawasan lingkungan yang bersih dan sehat, antar kampung di wilayah Kelurahan dan Kecamatan dalam Kota Jambi. Penelitian ini bertujuan untuk mendeskripsikan implementasi program kampung bantar di Kelurahan Eka Jaya Kecamatan Paal Merah Kota Jambi. Metode yang digunakan dalam penelitian ini adalah kualitatif dengan pendekatan deskriptif, data diperoleh dari sumber data primer dan data sekunder dengan teknik observasi,wawancara dan dokumentasi.Hasil penelitian menunjukkan bahwa model implementasi program kampung bantar di Kelurahan Eka Jaya Kecamatan Paal Merah Kota Jambi dilakukan melalui komunikasi, sumberdaya, disposisi dan struktur birokrasi sesuai dengan model Edward, Implementasi program ini sudah berjalan dengan baik, namun masih adanya hambatan dikarenakan rendahnya partisipasi masyarakat terhadap program ini meskipun telah disosialisasikan, serta mengikuti kampung bantar hanya saat penilaian saja dan selebihnya kategori kampung yang bersih, aman dan pintar itu tidak ada lagi. Kendala dalam implementasi terdiri atas sumber daya (partisipasi masyarakat dan dana dan dukungan (kerjasama). Serta upaya pemerintah daerah untuk meningkatkan partisipasi aktif masyarakat dilakukan dengan sosialisasi penyadaran pentingnya hidup sehat dan pemberian penghargaan.
\end{abstract}

Kata Kunci: Implementasi, Program, Program Kampung Bantar

\section{ABSTRACT}

The clean, safe and smart Village Program is the the Program of Jambi City Government which aims to make the smallest neighborhoods in the RT (neighborhood) neighborhood having a clean and healthy environment, between villages in the Kelurahan and Kecamatan within Jambi City. This study aims to describe the model of implementation of the bantar village program in Eka Jaya Village, Paal Merah District, Jambi City. The method used in this study was qualitative with a descriptive approach, data obtained from primary data sources and secondary data with observation, interviews and documentation techniques. The results of the study showed that the implementation model of the BANTAR village program in Eka Jaya Village, Paal Merah District, Jambi City were done through 
communication, resources, disposition and bureaucratic structure in accordance with Edward's model, the implementation of this program has been going well, but there are still obstacles due to the low community participation in this program even though it has been socialized, they just participated in bantar villages only during the assessment and the rest of the clean village categories, safe and smart no longer exists. Constraints in implementation consist of resources (community participation and funds and support (cooperation). As well as local government efforts to increase the active community participation are carried out by promoting awareness of the importance of healthy living and giving awards.

Keywords: Implementation, Program, Bantar Village Program

\section{PENDAHULUAN}

keadaan dan makhluk hidup, termasuk manusia dan perilakunya yang mempengaruhi alam itu sendiri, kelangsungan perikehidupan dan kesejahteraan manusia serta makhluk hidup lain (Pasal 1 ayat 1 UU Nomor 32 Tahun 2009 Tentang Perlindungan dan Pengelolaan Lingkungan Hidup).

Dalam rangka mempercepat pembangunan, Pemerintah Kota Jambi mengeluarkan suatu Peraturan Walikota Jambi Nomor 47 Tahun 2014 Tentang Petunjuk Teknis Penataan Kampung Bantar (Bersih, Aman dan Pintar). Adanya peraturan tersebut untuk mempercepat pembangunan setingkat wilayah Kecamatan, pemerataan pembangunan dan pengembangan sektor usaha mandiri kelompok masyarakat, serta meningkatkan motivasi swadaya dan semangat gotong royong masyarakat guna menciptakan suasana kompetitif yang sehat antar kampung diwilayah Kelurahan dan Kecamatan dalam Kota Jambi.

Pemerintah Kota Jambi membuat program tersebut karena jika ditinjau dari masalah kebersihan masih adanya masyarakat yang kurang peduli
Accepted: 2019-08-23

terhadap lingkungan tempat tinggalnya dan memudarnya rasa kesetiakawanan sosial untuk bergotong royong. Masalah keamanan tidak adanya pos kamling untuk masyarakat bersama-sama menjaga kampung di setiap malamnya dan masih ada kriminalitas pencurian dilingkungan tempat tinggal. Masalah pintar berdasarkan data pada Jambi.antarnews.com peringkat pendidikan jambi tahun 2016 berada pada peringkat 29 dari 34 provinsi di Indonesia, hal ini menunjukkan bahwa kesadaran belajar masyarakat di Kota Jambi masih relative rendah, karena itulah terkait dengan pendidikan selain lembaga formal Kota Jambi juga mengembangkan kesadaran belajar alternative melalui Kampung Bantar (bersih, aman dan pintar).

Dalam implementasi program kampung bersih, aman dan pintar di Kelurahan Eka Jaya Kecamatan Paal Merah Kota Jambi ini ditemui bahwa dari pelaksanaan kebijakan tersebut sudah berpatokan pada Keputusan Walikota Jambi No 47 Tahun 2014 Tentang Petunjuk Teknis Penataan Kampung Bantar dan berjalan sebagaimana yang diharapkan, namun masih adanya yang belum maksimal 
terhadap program kampung bantar (bersih, aman dan pintar) di Kelurahan Eka Jaya Kecamatan Paal Merah Kota Jambi dikarenakan rendahnya partisipasi masyarakat, tidak ada kepedulian terhadap lingkungan serta mengikuti kampung bantar hanya saat penilaian saja., hal ini diperkuat pada saat wawancara dengan Sarjana pendamping kampung bantar di Kecamatan Paal Merah, beliau menyatakan:

\begin{abstract}
“Tahap persiapan yaitu seleksi awal RT nominasi Kampung Bantar adanya masalah seperti rendahnya partisipasi masyarakat terhadap program ini meskipun telah di sosialisasikan kepada masyarakat setempat, tahap perencanaan dan pelaksanaan yaitu pembinaan, pemantauan dan penilaian terhadap RT nominasi kampung bantar adanya masalah seperti kesadaran bergotong royong tidak maunya masyarakat untuk berswadaya demi membangun kampung bantar dan tahap evaluasi yaitu monitoring terhadap hasil pembinaan terhadap RT pemenang Kampung Bantar adanya masalah seperti mengikuti kampung bantar (bersih, aman dan pintar) hanya saat penilaian saja dan selanjutnya kategori kampung bantar (bersih, aman dan pintar) itu tidak ada lagi".
\end{abstract}

Berdasarkan pernyataan diatas untuk menjaga kebersihan lingkungan tidak hanya dari diri kita sendiri, tetapi juga melibatkan kerja sama masyarakat serta kontribusi dari Pemerintah. Karena itulah Pemerintah Kota Jambi membuat suatu program bersih, aman dan pintar bagi lingkungan masyarakat. untuk melihat data pemenang kampung bersih, aman dan pintar dapat dilihat pada tabel 1.1 dibawah ini:

Tabel 1. Rekap Data Pemenang Kampung Bantar di Kelurahan Eka Jaya Kecamatan Paal Merah Tahun 2017-2018

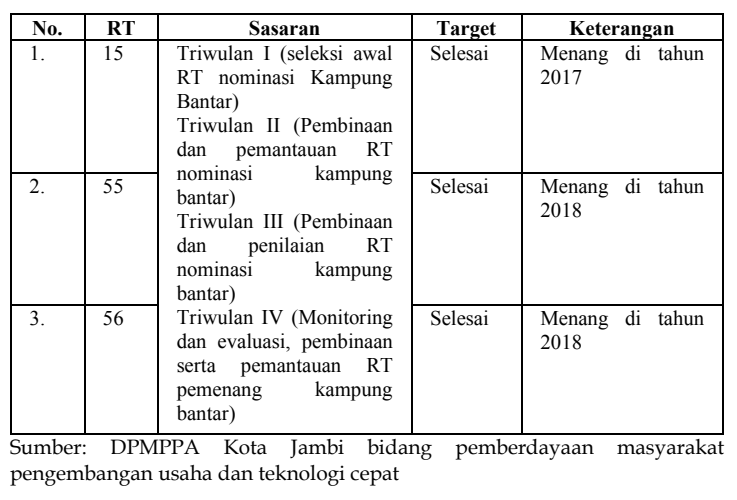

Berdasarkan tabel diatas bahwa RT 15, RT 55 dan RT 56 merupakan kawasan kampung bersih aman dan pintar, serta pernah memperoleh penghargaan. Namun pada observasi langsung ke lapangan di RT 15 Kelurahan Eka Jaya tidak lagi menerapkan kategori kampung bantar. Hal ini terlihat bahwa tidak adanya logo atau spanduk di kawasan daerah tersebut yang bertulisan kawasan kampung bantar (bersih, aman dan pintar), taman toga atau taman bermain anak tidak terjaga dengan baik, banyaknya semak atau tumbuh-tumbuhan liar,atribut pos kamling tidak lengkap dan terpenting kolam ikan lele yang dijadikan sebagai lahan kreatifitas bagi masyarakat untuk dijadikan sebagai usaha kelompok masyarakat tidak dimanfaatkan dengan baik.

Faktanya kesadaran masyarakat masih belum baik karena rasa disiplin, tanggung jawab dan peduli terhadap lingkungan yang sehat masih rendah. Mengikuti program kampung bantar (bersih, aman dan pintar) hanya saat penilaian saja dan selebihnya kategori yang dimaksud sebagai BANTAR (bersih, aman dan pintar) tidak ada lagi. RT 55 dan RT 56 Kelurahan Eka Jaya merupakan salah satu RT yang mengikuti kampung bantar (bersih, aman dan pintar) pada tahun 2018, serta di tahun 2018 ini memperoleh penghargaan sebagai kampung yang 
bersih, aman dan pintar. Hal ini terlihat saat observasi langsung kelapangan bahwa RT 55 dan RT 56 sebagai kampung yang dikategorikan BANTAR (bersih, aman dan pintar) yang memiliki slogan sebagai "KAMPUNG KECE" makna KECE adalah kreatif, edukatif, cerdas dan entrepreneur. RT 55 dan RT 56 tertata dengan rapi, hal ini terlihat adanya warna-warni pemukiman rumah, taman toga yang tersusun rapi, taman ramah anak dan manula, posyandu lansia, pos kamling, posko baca bagi anak, tersedia lahan jagung, adanya tempat sampah yang terletak disetiap rumah warga, dan lainnya. Beberapa hasil penelitian terdahulu yang telah ditelusuri sebagai berikut:

Hasil penelitian dari Imas (tahun 2018) tentang Implementasi Program Kotaku Dalam Menyelesaikan Persoala Lingkungan Kumuh Di Kricak Yogyakarta. Artikel ini bertujuan untuk mendeskripsikan implementasi dari program kotaku dan juga dampak yang dirasakan oleh masyarakat setempat dengan adanya penataan kawasan kumuh yang ada di berbagai wilayah Yogyakarta.

Selanjutnya Hasil penelitian dari Ruddy Oktarino Zakaria, Mochammad Makmur Dkk. Implementasi Program Sidoarjo Bersih Dan Hijau Yang Tertuang Dalam Surat Keputusan Bupati No 188 Tentang Tim Siduarjo Bersih Dan Hijau. Jurnal Administrasi Public Vol.2 No 4, Hal 666-672. Artikel ini bertujuan untuk mendeskripsikan dan menganalisis implementasi program SBH dan apa saja faktor pendukung dan penghambat dari Program SBH.

Perbedaan dari beberapa hasil penelitian diatas, maka dalam penelitian ini lebih berfokus kepada Implementasi program kampung bantar (bersih, aman dan pintar) di Kelurahan Eka Jaya Kecamatan Paal Merah Kota Jambi yang berkaitan dengan komunikasi, sumberdaya, disposisi dan struktur birokrasi, adapun kendala implementasi program kampung bantar (bersih, aman dan pintar) dan upaya Pemerintah Daerah meningkatkan partisipasi aktif masyarakat terhadap program kampung bantar (bersih, aman dan pintar) di Kelurahan Eka Jaya Kecamatan Paal Merah Kota Jambi.

\section{METODE PENELITIAN}

Jenis penelitian yang digunakan dalam penelitian ini adalah penelitian kualitatif dengan pendekatan deskriptif. Lokasi Penelitian yang ditetapkan peneliti adalah di RT 15, RT 55 dan RT 56 Kelurahan Eka Jaya Kecamatan Paal Merah Kota Jambi yang telah mengikuti program kampung bantar (bersih, aman dan pintar). Informan penelitian dilakukan dengan purposive sampling yang berjumlah 11 orang Unsur Pemerintah dan 10 masyarakat sasaran program kampung bantar (bersih, aman dan pintar) di Kelurahan Eka Jaya. Jenis data yang digunakan dalam penelitian ini adalah data primer dan data sekunder. Teknik pengumpulan data dilakukan dengan observasi, wawancara dan dokumentasi. Alat pengumpulan data yang digunakan pada penelitian ini adalah pedoman wawancara terhadap informan serta penggunaan handphone sebagai alat perekam, disamping itu peneliti juga mempergunakan kamera untuk keperluan dokumentasi serta observasi lapangan. Uji keabsahan 
data dengan teknik triangulasi data. Teknik analisis data yang digunakan dalam penelitian ini terdiri dari tiga komponen analisis yaitu, reduksi data, penyajian data dan penarikan kesimpulan.

\section{HASIL DAN PEMBAHASAN}

\section{Implementasi Program Kampung} Bantar (Bersih, Aman dan Pintar) Di Kelurahan Eka Jaya Kecamatan Paal Merah Kota Jambi

Dalam rangka terlaksanakanya program kampung bersih, aman dan pintar ini, maka perlu diberikan informasi kepada masyarakat yang akan di tunjuk kampung/tempat tinggalnya sebagai kampung bersih, aman dan pintar. Model Implementasi/pelaksanaan Program kampung bersih, aman dan pintar, memakai model implementasi oleh Edward yang terdiri dari komunikasi, sumberdaya, disposisi dan struktr birokrasi yang mengacu kepada tahap program kampung bantar yaitu tahap perencanaan

dan monitoring/evaluasi.

Komunikasi: Komunikasi sangat diperlukan didalam pelaksana program (kebijakan), komunikasi ini berkaitan dengan sosialisasi kepada sasaran program. Awal pembentukan kampung bantar (bersih, aman dan pintar) melakukan sosialisasi tentang pelaksanaan pembinaan kampung bantar kemasyarakat. Komunikasi berdasarkan model George C. Edward III (1980) dalam Mulyadi (2016:) keberhasilan implementasi kebijakan mensyaratkan agar implementor mengetahui apa yang harus dilakukan, apa yang menjadi tujuan dan sasaran kebijakan ditransmisikan kepada kelompok sasaran.

Berdasarkan data yang diperoleh dan hasil pengamatan dalam proses komunikasi program kampung bantar (bersih, aman dan pintar) di Kelurahan Eka Jaya Kecamatan Paal Merah, Bahwa Komunikasi dalam Tahap Persiapan/perencanaan program kampung bantar (bersih, aman dan pintar) telah dilaksanakan namun masih adanya penghambat dalam komunikasi kampung bantar. karena masih rendahnya partisipasi masyarakat terhadap program ini meskipun telah di sosialisasikan kepada masyarakat setempat. Namun juga masyarakat yang tidak merata menyebabkan sebagian masyarakat tidak mengetahui informasi komunikasi sosialisasi tentang program kampung bantar (bersih, aman dan pintar).

Sumber Daya: Menurut model George C. Edward III (1980) dalam Deddy Mulyadi (2016:68), sumberdaya merupakan hal penting dalam implementasi kebijakan maupun suatu program, baik itu sumber daya manusia maupun sumber daya non manusia. Tahap ini dilakukan pengumpulan data pada kampung bantar lalu dilakukan pembinaan serta pemantauan terhadap RT nominasi kampung bantar (bersih, aman dan pintar).

Berdasarkan data yang diperoleh dan hasil pengamatan dalam proses sumberdaya program kampung bantar (bersih, aman dan pintar) di Kelurahan Eka Jaya Kecamatan Paal Merah, bahwa mengupayakan sumber pembiayaan kampung bantar dari swadaya masyarakat dan partisipasi dari orang ketiga, serta mengkoordinasikan pembinaan kegiatan kampung bantar oleh pihak DPMP2A dan lainnya. Dikelurahan eka jaya, setelah dilakukan sosialiasasi maka selanjutnya melakukan 
pembinaan dan pemantauan terhadap RT nominasi kampung bantar. Membentuk program kampung bantar dilakukan berdasarkan swadaya masyarakat. Serta dalam pelaksanaan kegiatan baik itu kegiatan sosial, ekonomi maupun infrastruktur harus sesuai dengan perencanaan yang disusun dalam dokumen atau Keputusan Walikota Jambi No 47 Tahun 2014 Tentang Petunjuk Teknis Kampung Bantar.

Disposisi (sikap pelaksana): Disposisi Mulyadi (2016) yaitu kemauan, keinginan dan kecenderungan para perilaku kebijakan untuk melaksanakan kebijakan secara sungguh-sungguh sehingga apa yang menjadi tujuan kebijakan dapat diwujudkan sebagai program. Sebagai stakeholder program kampung bantar (bersih, aman dan pintar), para pegawai Kelurahan Eka Jaya dan Dinas Pemberdayaan Masyarakat, Perempuan dan Perlindungan Anak Kota Jambi sesuai dengan bidangnya masing-masing cenderung patuh dan melaksanakan apa yang menjadi tugas dan fungsi mereka.

Dari deskripsi hasil wawancara yang peneliti lakukan dapat diambil kesimpulan bahwa model Implementasi program kampung bantar (bersih, aman dan pintar) di Kelurahan Eka Jaya Kecamatan Paal Merah Kota Jambi dalam segi disposisi yang berhubungan dengan sikap para pelaksana kebijakan cenderung mempunyai pemahaman dan penerimaan yang baik terhadap program kampung bantar (bersih, aman dan pintar) ini meskipun ada yang tidak aktif.

Struktur Birokrasi: Menurut Mulyadi (2016) standard operating procedurs atau SOP menjadi pedoman bagi setiap implementor dalam bertindak. Jika struktur organisasi yang terlalu panjang akan cenderung melemahkan pengawasan dan menimbulkan masalah. Dalam hal ini struktur birokrasi di Kelurahan Eka Jaya Kota Jambi berjalan dengan baik. ditunjuknya Dinas Pemberdayaan Masyarakat, Perempuan dan Perlindungan Anak Kota Jambi tersebut sebagai stakeholder program kampung bantar (bersih, aman dan pintar) sesuai dengan bidang dan keahliannya masing-masing.

2. Kendala Dalam Implementasi Program Kampung Bantar (Bersih, Aman dan Pintar) Di Kelurahan Eka Jaya Kecamatan Paal Merah Kota Jambi

Dalam implementasi program kampung bantar (bersih, aman dan pintar) memiliki kendala yang terjadi selama kegiatan berlangsung, antara lain yaitu:

Sumberdaya (Partisipasi Masyarakat)

Dalam pengimplementasian program kampung bantar (bersih, aman dan pintar) di Kelurahan Eka Jaya Kecamatan Paal Merah Kota Jambi memiliki kendala mengenai keterlibatan masyarakat dalam program kampung bantar tersebut. Partisipasi adalah keikutsertaan seseorang atau sekelompok anggota masyarakat dalam suatu kegiatan, di luar pekerjaan atau profesinya sendiri. Keikutsertaan tersebut dilakukan sebagai akibat dari terjadinya interaksi sosial antara individu yang bersangkutan dengan anggota masyarakat yang lain (Raharjo,1983) dalam Mardikanto, 2015:81. Menurut Bambang Sunggono dalam Erwan Agus Purwanto (2015:86) Implementasi kebijakan didalam 
pelaksanaan program mempunyai beberapa faktor penghambat, yaitu: Isi kebijakan, penyebab lain dari timbulnya kegagalan implementasi suatu kebijakan public karena kekurangan yang menyangkut sumber daya-sumber daya pembantu, misalnya menyangkut waktu, biaya/dana dan tenaga manusia.

Pengembangan

program kampung bantar (bersih, aman dan pintar) yang belum tercapai secara maksimal dari segi sumber daya baik itu sumber daya manusia maupun sumber daya pendanaan, sumber daya merupakan hal penting dalam menjalankan suatu program, salah satunya adalah sumber daya manusia, anggaran dan informasi. Partisipasi inilah yang menjadi salah satu kendala dalam implementasi program kampung bantar (bersih, aman dan pintar) di Kelurahan Eka Jaya Kecamatan Paal Merah Kota Jambi ini.

Sebagaimana yang dikemukakan oleh Sarjana pendamping kampung bantar Kecamatan Paal Merah, bahwa dalam menumbuhkan kesadaran lingkungan masyarakat itu susah untuk berpartisipasi langsung pada saat pembentukan kampung bantar ditempat tinggalnya, mereka terlihat individual dari pada kumpul bersama untuk membuat kampung bantar (bersih, aman dan pintar). Selain sumberdaya manusia, Kendala yang ditemukan dilapangan pada dasarnya terletak pada sumber daya dari implementor program kampung bantar (bersih, aman dan pintar) masih kurang dan minimnya sumber daya finansial dari masyarakat mengenai dana pembentukan kampung bantar.

Hal ini merupakan salah satu kendala yang tidak maksimalnya pelaksanaan program kampng bantar (bersih, aman dan pintar) di Kelurahan Eka Jaya Kecamatan Paal Merah Kota Jambi.

\section{Dukungan (Kerja sama)}

Program kampung bantar (bersih, aman dan pintar) bekerja sama dengan instansi lain seperti Dinas Lingkungan Hidup Kota Jambi, Dinas Kebersihan dan Pertamanan Kota Jambi, Satpol PP dan lainnya serta yang terpenting adalah masyarakat itu sendiri. Namun kerja sama menjadi kendala dalam pelaksanaan program kampung bantar (bersih, aman dan pintar).

Menurut Bambang Sunggono dalam Erwan Agus Purwanto (2015:86) Implementasi kebijakan didalam pelaksanaan program mempunyai beberapa faktor penghambat, yaitu: Dukungan yaitu pelaksana suatu kebijakan sangat sulit apabila pada pengimplementasiannya tidak cukup dukungan untuk pelaksana kebijakan tersebut.

Terbukti bahwa setelah penghargaan diberikan terhadap kategori kampung yang mencerminkan bersih, aman dan pintar. Untuk mempertahankan kategori kampung bantar di tempat tinggal itu, kerja sama masyarakat memudar secara perlahan sehingga atribut ataupun kategori BANTAR itu tidak ada lagi. Seharusnya pihak pemerintah dengan masyarakat bekerja sama untuk tetap melakukan pembinaan agar kampung bantar ini tidak hanya dilakukan sebentar saat penilaian saja.

3. Upaya Pemerintah Daerah Meningkatkan Partisipasi Aktif Masyarakat Terhadap Program Kampung Bantar (Bersih, Aman dan Pintar) Di Kelurahan Eka Jaya Kecamatan Paal Merah Kota Jambi 
Sosialisasi penyadaran pentingnya hidup sehat

Penyadaran pentingnya hidup sehat merupakan upaya untuk meningkatkan semangat gotong royong dalam mendukung program pembangunan pemerintah dan kemasyarakatan guna menciptakan suasana kompetitif yang sehat antar kampung di wilayah kelurahan dan kecamatan dalam kota jambi untuk mencapai kategori kampung bersih, aman dan pintar. Berdasarkan Kamus Besar Bahasa Indonesia (KBBI) bahwa kata upaya berarti usaha, ikhtiar (untuk mencapai suat maksud, memecaghkan persoalan, mencari jalan keluar, dsb) artinya memiliki kesamaan arti dengan kata usaha dan demikian pula dengan kata ikhtiar serta upaya yang dilakukan dalam rangka mencapai suatu maksud, tujuan, pemecahan persoalan dan mencari jalan keluar. Adapun penyadaran pentingnya hidup sehat ini di lakukan pengolahan sampah yang harus dibedakan dari sampah organic dan nonorganic, pemanfaatan lahan kosong untuk ditanaman berbagai tanaman, mengadakan senam sehat dan berbagai kegiatan lainnya yang di selenggarakan pihak pemerintah bagi masyarakat di Kelurahan Eka Jaya Kecamatan Paal Merah Kota Jambi.

Pemberian penghargaan kampung bantar (bersih, aman dan pintar)

Untuk meningkatkan partisipasi masyarakat terhadap program kampung bantar ini, pemerintah melakukan upaya dengan memberikan penghargaan pada tahap akhir jika telah mengikuti program kampung bantar (bersih, aman dan pintar). Penghargaan ini dijadikan motivasi atau dorongan bagi RT yang tidak berpartisipasi atau mengikuti program tersebut. Sehingga melihat kampung yang lain bagus dan tertata rapi, masyarakat yang belum mengikuti program ini memiliki rasa ingin tahu dan juga ingin memiliki tempat tinggal yang berdasarkan bersih, aman dan pintar.

\section{KESIMPULAN}

Berdasarkan temuan penelitian dan pembahasan dapat disimpulkan bahwa Implementasi program kampung bantar (bersih, aman dan pintar) di Kelurahan Eka Jaya Kecamatan Paal Merah Kota sudah berjalan sebagaimana yang diharapkan. Namun masih belum maksimalnyabimplementasi program kampung bantar (bersih, aman dan pintar) di Kelurahan Eka Jaya Kecamatan Paal Merah Kota Jambi dikarenakan rendahnya partisipasi masyarakat, tidak ada kepedulian terhadap lingkungan serta mengikuti kampung bantar hanya saat penilaian saja dan selebihnya kategori kampung bantar (bersih, aman dan pintar) itu tidak ada lagi dan kembali seperti kehidupan yang awal. Terkait dengan bidang ilmu yang saya tekuni yaitu pemberdayaan masyarakat, sesuai dengan permasalahan diatas untuk memberdayakan masyarakat agar lebih peduli dengan kehidupan lingkungan yang bersih, aman dan pintar. Dilakukan adanya pembangunan secara menyeluruh agar tidak hanya masyarakat perkotaan saja yang bisa merasakannya tetapi juga busa dirasakan oleh masyarakat terkecil lingkup kampung/setingkat RT kecamatan dikota kota jambi.

Dampak positif dari penelitian yang dilakukan adalah terjadinya 
penambahan wawasan bagi masyarakat setempat untuk mampu lebih peduli dengan lingkungan tempat tinggalnya baik itu dari kebersihan, keamanan dan pendidikan. masyarakat mampu berkreatifitas dengan lahan yang ada untuk menghasilkan suatu barang daur ulang yang bisa menjadi nilai yang tinggi untuk di perjualkan. Sehingga apabila peneliti lain ingin meneliti terkait program kampung bantar (bersih, aman dan pintar), mungkin dapat meneliti secara detail bagaimana solusi lain terhadap sanksi masyarakat yang tidak berpartisipasi aktif terhadap program pemerintah tersbut.

Saran dari peneliti untuk peneliti selanjutnta ialah agar peneliti selanjutnya lebih dapat memberikan solusi yang lain karena solusi yang diberikan peniliti hanya pada batasan agar implementasi program kampung bantar (bersih, aman dan pintar) dikecamatan paal merah dapat dilaksanakan dengan baik.

\section{DAFTAR PUSTAKA}

Erwan, dan Sulistyastuti, Dyah Ratih (2015). Implementasi Kebijakan Publik: Konsep dan Aplikasinya di Indonesia. Yogyakarta: Gava Media.

Haris, Herdiansyah. (2011). Metodologi Penelitian Kualitatif Untuk IlmuIlmu Sosial. Jakarta: Salemba Humanika.

Kurniawa, Aditya Bagus Upaya Pemerintah Des Dalam Mendorong Partisipasi Masyarakat Dalam Pembangunan Desa Mandu Dalam Kecamatan Sangkulirang Kabupaten Kutai Timur. (2015). Jurnal
Administrasi Negara, Volume 3, Nomor 5, Tahun.

Mardikanto, Totok dan Soebianto, (2015). Pemberdayaan masyarakat dalam perspektif kebijakan publik. Bandung: Alfabeta.

Mulyadi, D. (2016). Studi Kebijakan Public Dan Pelayanan Publik. Bandung: Penerbit Alfabeta..

NC, Herbasuki. (2016). Implementasi Program Nasional Pemberdayaan Masyarakat (PNPM) Dikota Semarang. Jurnal Manajemen dan Kebijakan Politik. Vol 2 (1),

Peraturan Walikota Jambi Nomor 47 Tahun 2014 Tentang Petunjuk Teknis Pelaksanaan Kampung Bantar.

Deni. (2014). Implementasi program pengembangan budidaya kakao di kabupaten pasaman. Skripsi. Universitas Negeri Padang.

Zakaria, R. O. (2014). Implementasi Program Sidoarjo Bersih dan Hijau yang Tertuang dalam Surat Keputusan Bupati No 188 tentang Tim Sidoarjo Bersih dan Hijau (Studi pada Dinas Kebersihan dan Pertamanan Kabupaten Sidoarjo). Jurnal Administrasi Publik, 2(4), 666672.

Undang-Undang Nomor 32 Tahun 2009 Tentang Perlindungan dan Pengelolaan Lingkungan Hidup

Widiyanti Imas. (2018). Implementasi Program Kotaku Dalam Menyelesaikan Persoalan Lingkungan Kumuh Di Kricak Yogyakarta. Skripsi. Universitas Islam Negeri Sunan Kalijaga Yogyakarta.

https://jambikota.go.id/new/kampu ngbantar/ (Akses tanggal 2 
oktober 2018, Website resmi kota jambi)

http://kampungbantarkotajambi.blog spot.co.id (Website resmi kampung bantar)

www.jambi.independent.co.id Tanggal 14 mei 2018 (percepat pembangunan melalui program bangkit berdaya dan kampung bantar.

metrojambi.com/read/2018/05/18/3 2078/percepat-pembangunanmelalui-program-bangkitberdaya-dan-kampung-bantar Tanggal 14 mei 2018

wartanews.co/dlh-kotajambimengapresiasipembentukan-kampungkampung-berwawasan lingkungan/ Tanggal 14 mei 2018. 